\title{
Effect of Austenite-to-Ferrite Phase Transformation at Grain Boundaries on PWHT Cracking Susceptibility in CGHAZ of T23 Steel
}

\author{
Seong-Hyeong Lee ${ }^{1}$, Hye-Sung $\mathrm{Na}^{2}{ }^{2}$, Kyong-Woon Lee ${ }^{3}$, Jeong-Yong Lee ${ }^{2}$ \\ and Chung Yun Kang ${ }^{2, *}$ \\ 1 Department of Hybrid Materials \& Machining Technology, Graduate School of Convergence Science, \\ Pusan National University, Busan 46241, Korea; reach486@naver.com \\ 2 Department of Material Science and Engineering, Pusan National University, Busan 46241, Korea; \\ joyclubman@daum.net (H.-S.N.); jy689654@gmail.com (J.-Y.L.) \\ 3 Corporate R\&D Institute, Doosan Heavy Industries, Changwon 642-792, Korea; \\ kyongwoon.lee@doosan.com \\ * Correspondence: kangcy@pusan.ac.kr; Tel.: +82-10-8329-8429
}

Received: 11 May 2018; Accepted: 1 June 2018; Published: 4 June 2018

\begin{abstract}
The post-weld heat treatment (PWHT) cracking susceptibility of a coarse grain heat-affected zone (CGHAZ) in SA213-T23 (2.25Cr-1.6W steel) that was used for boiler tubes employed in thermal power plants was investigated using a Gleeble thermal cycle simulator. The PWHT cracking susceptibility test was performed at $650^{\circ} \mathrm{C}, 700^{\circ} \mathrm{C}$, and $750^{\circ} \mathrm{C}$, and it can be judged that the lower the reduction of the area, the more susceptible it is to PWHT cracking. The results of the test also showed higher cracking susceptibility at $650{ }^{\circ} \mathrm{C}$ and $700{ }^{\circ} \mathrm{C}$, which mostly involved intergranular fracture, while at $750{ }^{\circ} \mathrm{C}$, transgranular fracture was exhibited. Therefore, the PWHT cracking susceptibility is considered to be closely related to grain boundary. The microstructure of the simulated CGHAZ and PWHT at $650{ }^{\circ} \mathrm{C}, 700{ }^{\circ} \mathrm{C}$, and $750{ }^{\circ} \mathrm{C}$ was observed after etching with nital and alkaline sodium picrate etchants. Alkaline sodium picrate-etched microstructures showed a white band at the grain boundary at $650{ }^{\circ} \mathrm{C}, 700{ }^{\circ} \mathrm{C}$, and $750{ }^{\circ} \mathrm{C}$, which did not appear in nital etching. An analysis of the white band using an electron probe micro-analyzer (EPMA), TEM, and nanoindentation revealed that it was intergranular ferrite depleted with $\mathrm{C}, \mathrm{W}$, and $\mathrm{Cr}$ as compared with that in the matrix. Based on these results, we investigated the mechanism of intergranular ferrite formation during PWHT and its effect on PWHT cracking susceptibility at $650{ }^{\circ} \mathrm{C}, 700{ }^{\circ} \mathrm{C}$, and $750{ }^{\circ} \mathrm{C}$.
\end{abstract}

Keywords: SA213-T23; Cr-Mo steel; CGHAZ; PWHT cracking; intergranular ferrite; tint etching

\section{Introduction}

In order to achieve a higher efficiency of thermal power plants, pipes and tubes used therein are increasingly required to sustain higher temperatures and pressures [1,2]. Therefore, SA213-T23 (2.25Cr-1.6W steel), which has better high-temperature creep strength than SA213-T22 (2.25Cr-1Mo steel), has been developed as a candidate material.

To develop SA213-T23 (2.25Cr-1.6W steel), SA213-T22 (2.25Cr-1Mo steel) was modified by the addition of tungsten $(1.6 \%)$, a reduction of molybdenum $(0.2 \%)$ and carbon content $(0.04-0.10 \%)$, and small additions of vanadium, nitrogen, and boron [3-7].

However, in the case of T23 material, PWHT cracking (reheat cracking) has been reported in the process of post-weld heat treatment (PWHT) to mitigate the residual stress in the weld metal [8-16]. Therefore, much research has been conducted to analyze the cause of the formation of reheat cracks in $2.25 \mathrm{Cr}-1.6 \mathrm{~W}$ steel. Nawrocki et al. explained that the cause of reheat cracking is due to the weakening 
of the grain boundary by (1) the Cr-depleted and W-depleted zones formed by the $\mathrm{M}_{3} \mathrm{C}$ and $\mathrm{M}_{23} \mathrm{C}_{6}$ carbides of $\mathrm{Fe}, \mathrm{Cr}$, and $\mathrm{W}$ in the grain boundaries [12,13], (2) the precipitation of an incoherent intergranular carbide M3C at the boundaries [4,5], (3) the grain boundary segregation of the $\mathrm{Al}$ and $\mathrm{P}$ elements [11,12], and (4) transgranular strengthening by the homogeneous precipitation of a fine metal carbide containing the alloying elements $\mathrm{V}$ and $\mathrm{Nb}$ [11-13].

Previous studies had been carried out from the viewpoint that the alloy components of the matrix are homogeneous. However, the research of Belde et al. recently found that there is a microsegregation in the matrix where the alloying elements are not uniform, which can affect the mechanical properties and cause cracking in the course of the heat treatment $[17,18]$. According to Lee et al., the $\mathrm{M}_{23} \mathrm{C}_{6}$ precipitate of the base metal in 2.25Cr-1Mo-Ti steel partially dissolves in the thermal cycle of CGHAZ, and the microsegregation of $C$ and $C r$ appears as a black stripe $[19,20]$. It is considered that such a microsegregation can affect the mechanical properties of PWHT due to phase transformation other than the matrix.

Many researchers have studied reheat cracking, but this study aims to investigate the effect of microsegregation on the reheat cracks in the matrix during PWHT, as there has been very little research on this aspect.

\section{Materials and Methods}

Table 1 presents the chemical composition of the SA213-T23 (2.25Cr-1.6W) material used in this study, which was analyzed using an optical emission spectrometer (LAB LAVM 10, SPECTRO Analytical Instruments $\mathrm{GmbH}$, Kleve, Germany).

Table 1. Chemical composition of the T23 steel.

\begin{tabular}{cccccccccccccccc}
\hline \multirow{2}{*}{ Material } & \multicolumn{11}{c}{ Chemical Composition (at. \%) } \\
\cline { 2 - 7 } & $\mathbf{C}$ & $\mathbf{S i}$ & $\mathbf{M n}$ & $\mathbf{N i}$ & $\mathbf{C r}$ & $\mathbf{M o}$ & $\mathbf{V}$ & $\mathbf{N b}$ & $\mathbf{A l}$ & $\mathbf{T i}$ & $\mathbf{B}$ & $\mathbf{W}$ & $\mathbf{N}$ & $\mathbf{F e}$ \\
\hline SA213-T23 & 0.07 & 0.24 & 0.50 & 0.11 & 2.09 & 0.15 & 0.22 & 0.028 & 0.018 & 0.042 & 0.0017 & 1.66 & 0.0095 & Bal \\
\hline
\end{tabular}

In actual welding, it is impossible to carry out an evaluation of the mechanical properties, because the heat-affected zone (HAZ) is a narrow region owing to various thermal cycles. Therefore, the PWHT cracking test was performed by using the Gleeble 3500 (Dynamic Systems Inc., New York, NY, USA) thermal cycle simulator to reproduce the thermal cycle curve $\left(1350{ }^{\circ} \mathrm{C}\right.$ peak) of the coarse grain heat-affected zone (CGHAZ), which was calculated by using the Sysweld software 9.5 (ESI, Paris, France) for simulation of the welding analysis. The welding conditions used in the Sysweld calculations are as follows: weld method: gas tungsten arc welding (GTAW), heat input: $16 \mathrm{~kJ} / \mathrm{cm}$, thickness: $6 \mathrm{~mm}$.

Figure 1 shows the schematic diagram and specimen geometry of the PWHT cracking test. After $30 \mathrm{~min}$ at PWHT temperatures $\left(650^{\circ} \mathrm{C}, 700^{\circ} \mathrm{C}, 750^{\circ} \mathrm{C}\right)$, the tensile test was performed at a very low strain rate $\left(2.5 \times 10^{-4}\right)$. As a result of the PWHT test, if the reduction in area is low, it is concluded that cracking is likely to occur because of low grain boundary ductility, and sensitivity to reheat cracking is higher. The reason for the tensile test at a very low strain rate $\left(2.5 \times 10^{-4}\right)$ is to prevent plastic deformation before the brittle fracture mode due to PWHT cracking.

The microstructure of the simulated CGHAZ and PWHT was observed by etching it with nital etchant ( $2 \mathrm{~mL} \mathrm{HNO}_{3}, 50 \mathrm{~mL}$ methanol) and alkaline sodium picrate etchant ( $2 \mathrm{~g}$ picric acid, $25 \mathrm{~g} \mathrm{NaOH}$, $100 \mathrm{~mL}$ boiled water). The fracture surface was observed by using a scanning electron microscope (SEM) (SUPRA40VP, Carl Zeiss, Oberkochen, Germany). The phase analysis of the simulated CGHAZ and PWHT was performed using an electron probe micro-analyzer (EPMA) (JXA-8530F, JEOL, Tokyo, Japan) and field-emission transmission electron microscope (FE-TEM) (TALOS F200X, FEI, Hillsboro, OR, USA), and the time-temperature-transformation diagram (TTT diagram) was obtained by using JMatPro 5.1 software (Sente Software, Surrey Research Park, UK) to analyze the experimental results. 


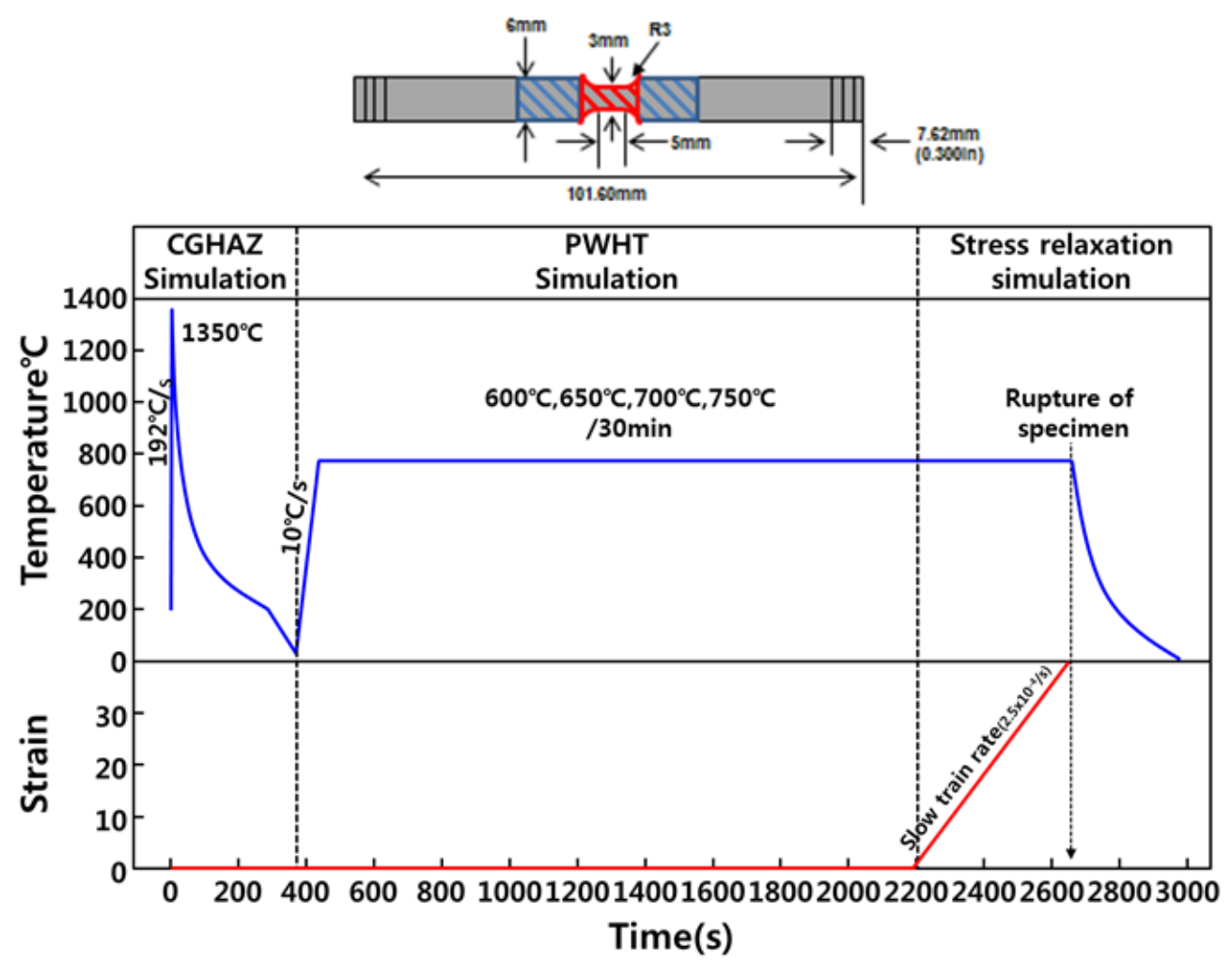

Figure 1. Schematic illustration of a post-weld heat treatment (PWHT) cracking susceptibility test at various PWHT temperatures, and the geometry of the sample.

A thin-film specimen of CGHAZ for TEM analysis was prepared by mechanical polishing, followed by jet electropolishing using an electrolyte consisting of a mixture of $95 \%$ methanol and $5 \%$ perchloric acid, maintained at a temperature of $20^{\circ} \mathrm{C}$. A thin-film specimen of $700{ }^{\circ} \mathrm{C}$ was prepared using the focused ion beam (FIB) (FEI Scios, Thermo Fisher Scientific, Hillsboro, OR, USA).

The transgranular hardness was measured using a Vickers hardness tester (HM-200, Mitutoyo Corporation, Kanagawa, Japan), and the hardness near the grain boundaries by using a nanoindenter (TI-950, HYSITON, Minneapolis, MN, USA).

\section{Results and Discussion}

\subsection{PWHT Cracking Susceptibility Test}

Figure 2 shows the results of the PWHT cracking susceptibility test of CGHAZ at various temperatures. The test was performed by holding the simulated CGHAZ at PWHT temperatures $\left(650{ }^{\circ} \mathrm{C}, 700{ }^{\circ} \mathrm{C}, 750{ }^{\circ} \mathrm{C}\right)$ for $30 \mathrm{~min}$, and then, the tensile test was performed under the strain rate condition of $2.5 \times 10^{-4}$.

As the PWHT temperature increases, the tensile strength tends to decrease almost linearly to $619 \mathrm{MPa}, 466 \mathrm{MPa}$, and $278 \mathrm{MPa}$ at $650{ }^{\circ} \mathrm{C}, 700{ }^{\circ} \mathrm{C}$, and $750{ }^{\circ} \mathrm{C}$, respectively. On the other hand, the reduction in area and elongation are low at $10.4 \%$ and $5.9 \%$ at $650{ }^{\circ} \mathrm{C}$, and $9.7 \%$ and $5.2 \%$ at $700{ }^{\circ} \mathrm{C}$, respectively. However, the reduction in area and elongation at $750{ }^{\circ} \mathrm{C}$ increased to $40.0 \%$ and $22.5 \%$, respectively. It is found that the lower the reduction in area, the more the susceptibility to PWHT cracking [21-23]; in other words, CGHAZ is susceptible to PWHT cracking at $650{ }^{\circ} \mathrm{C}$ and $700{ }^{\circ} \mathrm{C}$, but not at $750^{\circ} \mathrm{C}$. 


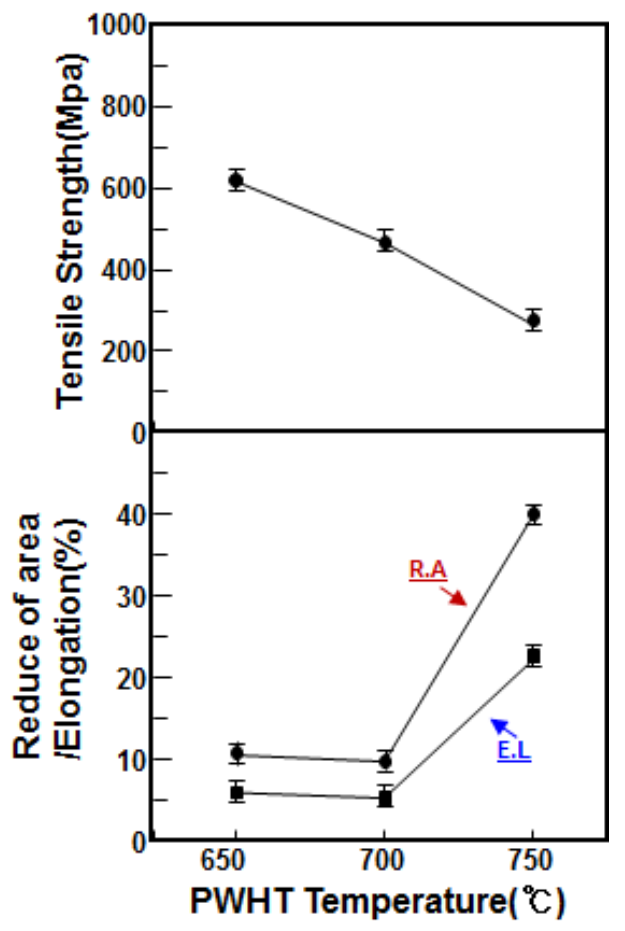

Figure 2. Results of PWHT cracking test at various temperatures.

In order to analyze the correlation between PWHT cracking susceptibility and fracture surface, the fracture surfaces of specimens that failed during the testing at $650{ }^{\circ} \mathrm{C}, 700{ }^{\circ} \mathrm{C}$, and $750{ }^{\circ} \mathrm{C}$ were observed by SEM, as shown in Figure 3. The surfaces at $650{ }^{\circ} \mathrm{C}$ and $700{ }^{\circ} \mathrm{C}$ shown in Figure $3 \mathrm{a}, \mathrm{b}$ largely appear as intergranular fractures, which are generally sensitive to PWHT and considered to have lower intergranular strength than transgranular strength. Figure $3 \mathrm{~d}$,e are the enlargements of the $X$ and $Y$ regions in Figure 3a,b, respectively, and show that the grain boundaries are covered by fine dimples. The surface at $750^{\circ} \mathrm{C}$ shown in Figure 3c, which is not sensitive to PWHT cracking, mostly appears as a transgranular fracture. Therefore, it is considered that the intergranular strength is not lower than the transgranular strength at $750{ }^{\circ} \mathrm{C}$. As a result of the fracture surface analysis, the reheat cracking sensitivity is considered to be correlated with intergranular and transgranular strengths.
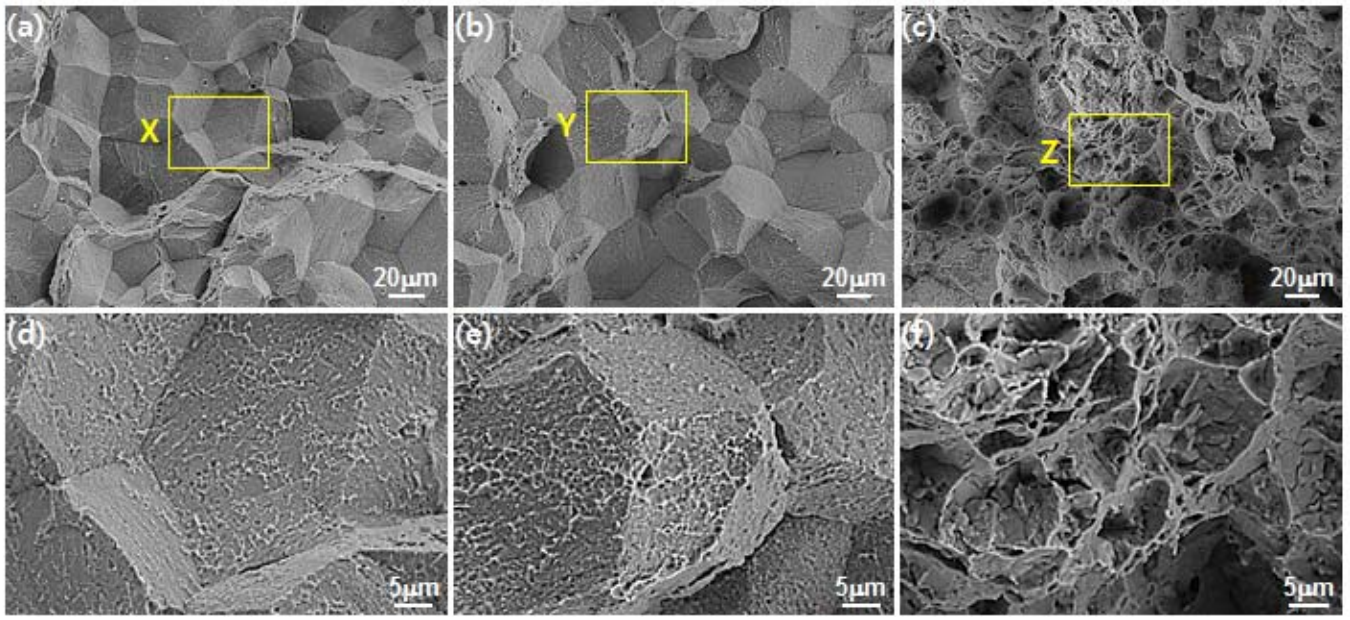

Figure 3. Representative SEM photomicrographs of the fracture surfaces of specimens that failed during testing at (a) $650{ }^{\circ} \mathrm{C},(\mathbf{b}) 700{ }^{\circ} \mathrm{C}$, and (c) $750{ }^{\circ} \mathrm{C}$. Enlarged SEM photomicrographs (d-f) at regions denoted by $\mathrm{X}, \mathrm{Y}$, and $\mathrm{Z}$. 


\subsection{Correlation between Microstructure and PWHT Cracking Susceptibility}

Figure 4 shows the optical microscopic structure of CGHAZ at PWHT temperatures $\left(650{ }^{\circ} \mathrm{C}\right.$, $700{ }^{\circ} \mathrm{C}, 750{ }^{\circ} \mathrm{C}$ ) using nital and alkaline sodium picrate etching. In order to compare the differences between nital and alkaline sodium picrate etching, the microstructure was observed after nital etching, and it was subsequently finely polished. Afterward, alkaline sodium picrate etching was performed to observe the same position as that observed in nital etching, and the differences in the microstructures owing to etching.

The nital-etched microstructure of CGHAZ reveals the prior austenite grain boundary and lath in the matrix. The PWHT conditions at $650{ }^{\circ} \mathrm{C}, 700{ }^{\circ} \mathrm{C}$, and $750{ }^{\circ} \mathrm{C}$ also showed the prior austenite grain boundary and lath in the matrix. The alkaline sodium picrate-etched microstructure of the CGHAZ also shows the prior austenite grain boundary and lath in the matrix, as in the case of nital etching, but with a black band that was not observed in the nital-etched microstructure. According to Lee's study, the $\mathrm{M}_{23} \mathrm{C}_{6}$ precipitates of the base metal are due to partial dissolution in the CGHAZ thermal cycle, and are not completely dissolved, and the fine segregation of the remaining $\mathrm{C}, \mathrm{W}$, and $\mathrm{Cr}$ appears as a black band in the CGHAZ [19].

White bands are not observed at the grain boundaries of CGHAZ. However, when PWHT is performed at $650{ }^{\circ} \mathrm{C}, 700{ }^{\circ} \mathrm{C}$, and $750{ }^{\circ} \mathrm{C}$, white bands appeared at the grain boundaries, which was different from the observation in CGHAZ. There is also a black band at $650{ }^{\circ} \mathrm{C}, 700{ }^{\circ} \mathrm{C}$, and $750{ }^{\circ} \mathrm{C}$, which suggests that $C, W$, and $C r$ segregations of CGHAZ are not diffused, even under PWHT. The presence of $C, W$, and Cr segregation in the PWHT was also examined in the EPMA analysis.
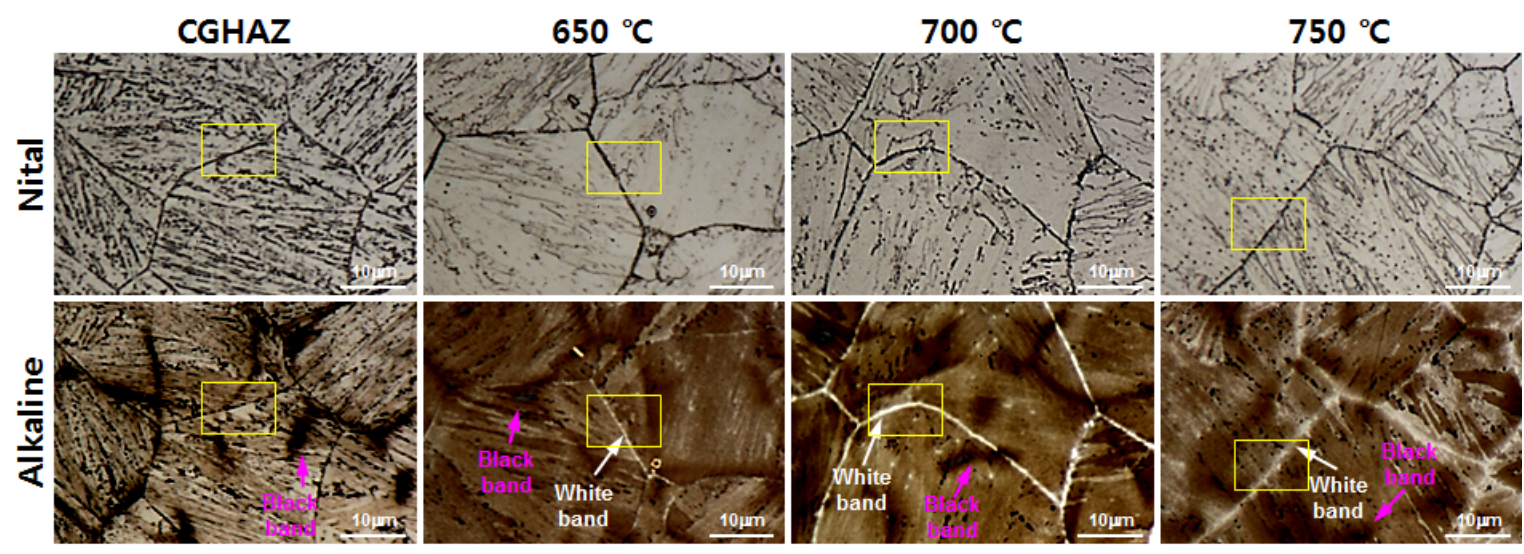

Figure 4. Optical microstructure with etchants (nital, alkaline sodium picrate) at various PWHT temperatures. (The yellow rectangle is the position observed by SEM in Figure 5).

Figure 5 shows the SEM structure of the CGHAZ at PWHT temperatures $\left(650{ }^{\circ} \mathrm{C}, 700{ }^{\circ} \mathrm{C}, 750{ }^{\circ} \mathrm{C}\right)$ using nital and alkaline sodium picrate etching. The observed part is shown in Figure 4 as the $\square$ area. Nital-etched SEM microstructures show a line at the grain boundaries of the CGHAZ. However, in PWHT at $650{ }^{\circ} \mathrm{C}, 700{ }^{\circ} \mathrm{C}$, and $750{ }^{\circ} \mathrm{C}$, precipitates were observed instead of lines at the grain boundaries. Therefore, it is considered that the line of CGHAZ is transformed into precipitate during PWHT.

On the other hand, in the alkaline sodium picrate-etched microstructure, neither lines nor precipitates at grain boundaries in either CGHAZ or PWHT were observed clearly. In nital etching, the grain boundaries and precipitates are clearly visible because the matrix is reduced. However, they are not seen clearly in alkaline sodium picrate etching, because the matrix is not reduced. 

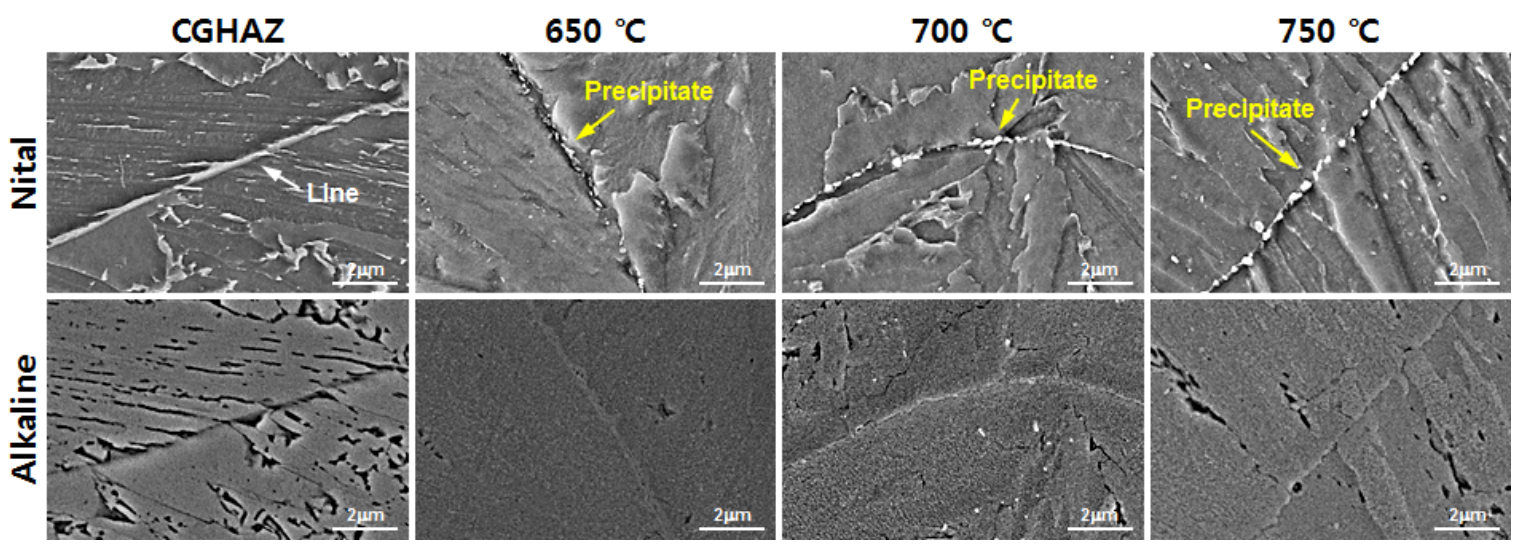

Figure 5. SEM microstructure with etchants (nital, alkaline sodium picrate) at various PWHT temperatures.

Figure 6 shows the results of the TEM analysis of the precipitates using the carbon replica method in order to identify the phases of the precipitates at the grain boundaries at PWHT temperatures. The diffraction pattern of the line at the grain boundaries in CGHAZ could not be obtained, and it was considered that it was not extracted from the carbon replica. The PWHT conditions at $650{ }^{\circ} \mathrm{C}, 700{ }^{\circ} \mathrm{C}$, and $750{ }^{\circ} \mathrm{C}$ showed precipitates at the grain boundaries, and the diffraction pattern analysis of these revealed that it was $\mathrm{M}_{23} \mathrm{C}_{6}$ carbide. Observation of the microstructure shows that a line exists at the grain boundaries of $\mathrm{CGHAZ}$, and white bands and $\mathrm{M}_{23} \mathrm{C}_{6}$ appear at $650{ }^{\circ} \mathrm{C}, 700{ }^{\circ} \mathrm{C}$, and $750{ }^{\circ} \mathrm{C}$ when PWHT is performed.

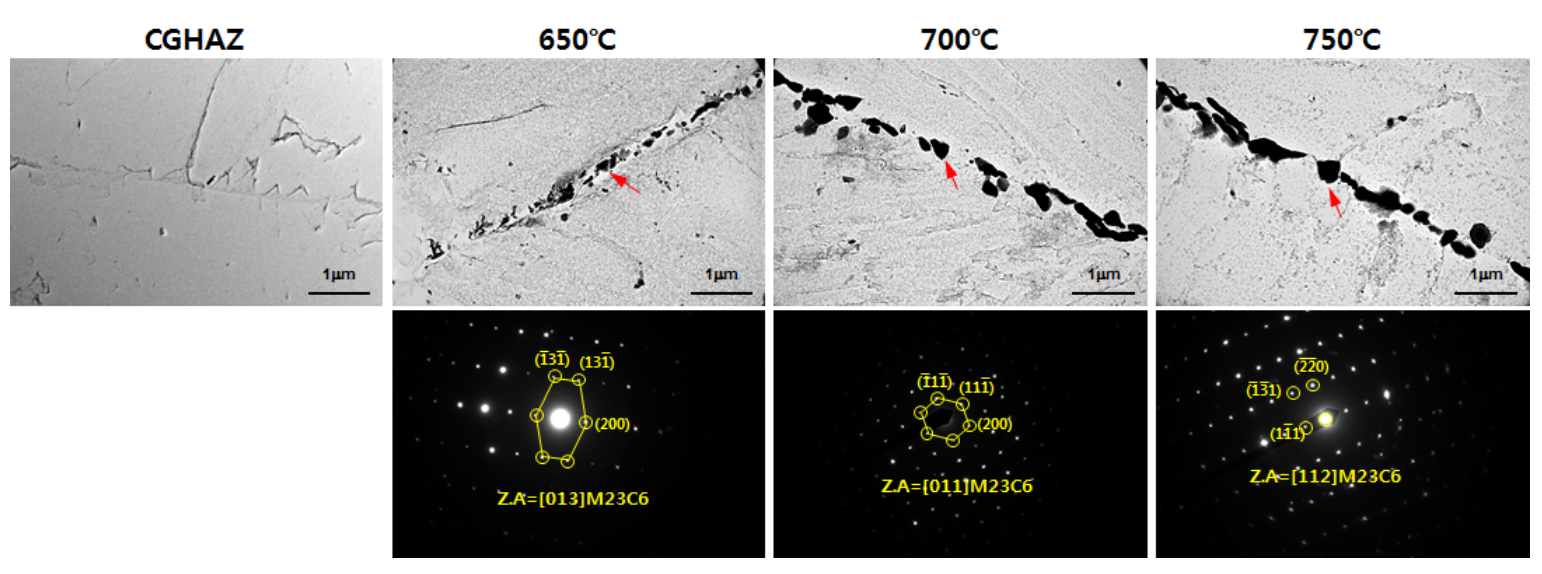

Figure 6. TEM microstructures and diffraction patterns at the regions denoted by arrows at various PWHT temperatures.

Figure 7 shows the results of EPMA mapping for analyzing the alloy compositions of the white bands and $\mathrm{M}_{23} \mathrm{C}_{6}$ carbide at the grain boundaries, and the black band at $700{ }^{\circ} \mathrm{C}$. The white band at the grain boundary at $700{ }^{\circ} \mathrm{C}$ can be observed to be depleted of C; $\mathrm{W}$ and $\mathrm{Cr}$ are not clearly visible, but appear to be depleted. The $\mathrm{M}_{23} \mathrm{C}_{6}$ intergranular precipitates inside the white band are concentrated in $C, W$, and $C r$. It is considered that the depleted zone is formed around the $\mathrm{M}_{23} \mathrm{C}_{6}$ precipitate because the $\mathrm{M}_{23} \mathrm{C}_{6}$ carbide with high $\mathrm{C}, \mathrm{W}$, and $\mathrm{Cr}$ components precipitates at the grain boundary [24-27] when PWHT is carried out at $700{ }^{\circ} \mathrm{C}$. According to a study by Lee et al., the black band in alkaline sodium picrate-etched CGHAZ is the segregated region of C, W, and Cr [19,20]. The black band at $700{ }^{\circ} \mathrm{C}$ is also a region where $\mathrm{C}, \mathrm{W}$, and $\mathrm{Cr}$ components are concentrated. It can be seen that even if PWHT is performed, $\mathrm{C}, \mathrm{W}$, and $\mathrm{Cr}$ are not diffused, but rather remain as segregation regions. 

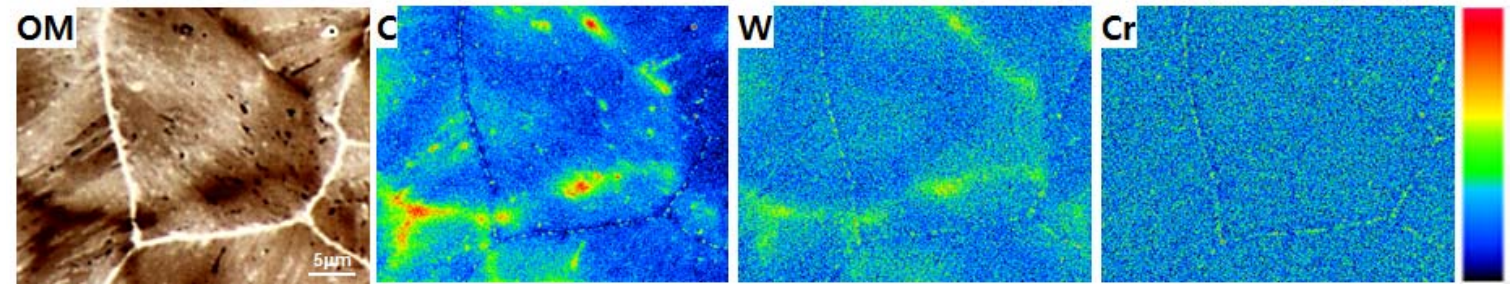

Figure 7. Electron probe microanalyzer (EPMA) mapping results showing the distribution of elements at $700{ }^{\circ} \mathrm{C}$.

To summarize, at $700{ }^{\circ} \mathrm{C}$, the white band of the grain boundaries is a $\mathrm{C}, \mathrm{W}$, and $\mathrm{Cr}$-depleted zone; M23C6 precipitates in which $\mathrm{C}, \mathrm{W}$, and $\mathrm{Cr}$ components are concentrated are present in the white band, and the black band is an area concentrated in $\mathrm{C}, \mathrm{W}$, and $\mathrm{Cr}$. At $650{ }^{\circ} \mathrm{C}$ and $750{ }^{\circ} \mathrm{C}$, it can be considered that the white band is the region where $\mathrm{C}, \mathrm{W}$, and $\mathrm{Cr}$ are depleted, and the black band is a region where $\mathrm{C}, \mathrm{W}$, and $\mathrm{Cr}$ are concentrated.

In order to identify the phase of the white band at the grain boundary, the specimen was prepared using a FIB on the grain boundaries at $700{ }^{\circ} \mathrm{C}$ and observed using TEM. In the low-magnification TEM photograph of Figure 8, bands and precipitates are observed at the grain boundary. In Figure 8b, which is an enlarged view of the region $X_{1}$ of the grain boundary, a black dot is observed inside the band, which looks like a precipitate or dislocation. However, in the high resolution (HR) image of Figure $8 c$, which enlarges the $X_{2}$ region of Figure $8 b$, the band and black dot have the same atomic arrangement. Therefore, the black spot inside the band is judged to be a dislocation, and not a precipitate. A diffraction pattern analysis of the $Y_{1}$ region was performed to identify the phase of the bands and precipitates. As a result of the analysis, the band of the grain boundary, which was a body-centred cubic (BCC) structure, was judged to be intergranular ferrite because there was no transgranular precipitation, although there was dislocation, and the precipitate of the grain boundary was $\mathrm{M}_{23} \mathrm{C}_{6}$.
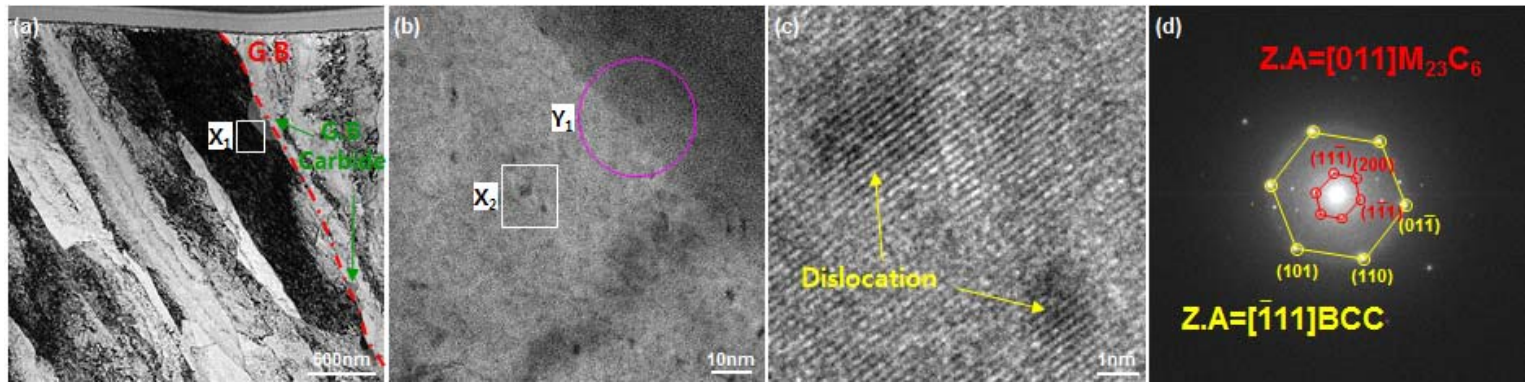

Figure 8. (a) TEM micrograph at $700{ }^{\circ} \mathrm{C}$; (b) Enlarged micrograph of the region denoted by $\mathrm{X}_{1}$; (c) HR-TEM micrograph of the region denoted by $\mathrm{X}_{2}$; (d) Diffraction pattern of the region denoted by $\mathrm{Y}_{1}$.

Figure 9 is the result of the analysis with a nanoindenter to compare the hardness of the intergranular ferrite with the matrix at $700{ }^{\circ} \mathrm{C}$. In order to measure the hardness of intergranular ferrite with a thickness of $1.0 \sim 1.2 \mu \mathrm{m}$, the indenter size was tested to be $0.5 \mu \mathrm{m}$ or less. As a result of the nanoindentation analysis, it can be seen that the hardness of intergranular ferrite is 3.92 3.94 GPa, which is lower than that of the matrix, which is $4.43 \sim 4.51 \mathrm{GPa}$. As a result of EPMA, nanoindentation, and TEM analysis, the white band at the grain boundary in alkaline sodium picrate etching at $650{ }^{\circ} \mathrm{C}$, $700{ }^{\circ} \mathrm{C}$, and $750{ }^{\circ} \mathrm{C}$ is identified to be intergranular ferrite where $\mathrm{C}, \mathrm{W}$, and $\mathrm{Cr}$ are depleted more than in the matrix, and intergranular ferrite has a lower hardness than the matrix at $700{ }^{\circ} \mathrm{C}$. 


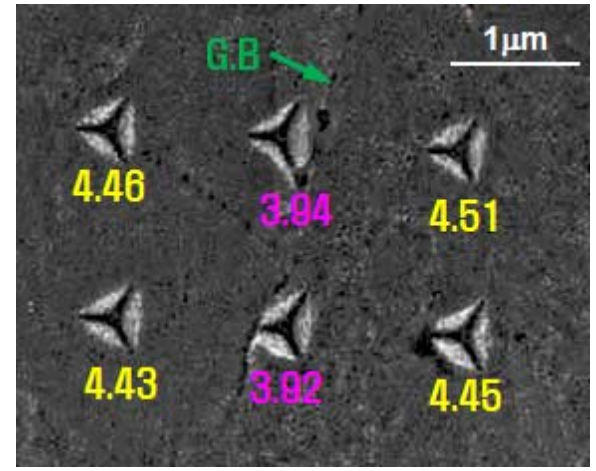

Figure 9. Nanoindentation results showing hardness at $700{ }^{\circ} \mathrm{C}$.

Therefore, it is considered that ductile intergranular ferrite is generated in the grain boundary when PWHT is carried out at $700{ }^{\circ} \mathrm{C}$, thereby lowering the intergranular strength. This is the reason why intergranular fracture appears largely at $700{ }^{\circ} \mathrm{C}$ and is sensitive to PWHT. The fracture surfaces at $650{ }^{\circ} \mathrm{C}$ and $700{ }^{\circ} \mathrm{C}$ in Figure 3 appear as intergranular fractures mostly covered with fine dimples at the grain boundaries, which is attributed to ductile intergranular ferrite, and sensitive to reheat cracks. However, the fracture surface at $750{ }^{\circ} \mathrm{C}$ was mostly transgranular, and not sensitive to reheat cracking. It is considered that the intergranular strength is lower than transgranular strength at $650{ }^{\circ} \mathrm{C}$ and $700{ }^{\circ} \mathrm{C}$. However, this is not the case at $750{ }^{\circ} \mathrm{C}$.

Figure 10 shows the micro-Vickers hardness of the matrix for various PWHT temperatures. The matrix hardness at $650^{\circ} \mathrm{C}$ was similar to that of the CGHAZ despite PWHT, and decreased at $700{ }^{\circ} \mathrm{C}$ and $750{ }^{\circ} \mathrm{C}$ as the temperature increased. Generally, the greater the hardness, the greater the strength [28-30]. Therefore, it is expected that as the PWHT temperature increases, the transgranular strength decreases due to the tempering effect. Therefore, the transgranular strength at $700{ }^{\circ} \mathrm{C}$ is greater than the intergranular strength, which is weakened by intergranular ferrite, but at $750{ }^{\circ} \mathrm{C}$, it is expected to be similar to or lower than the intergranular strength.

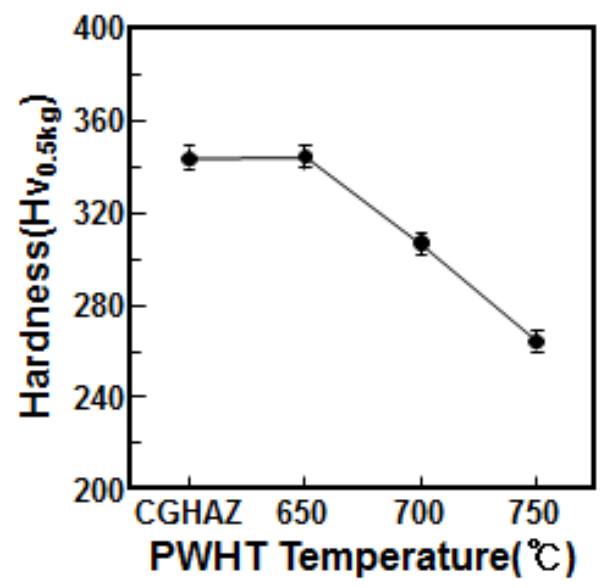

Figure 10. Comparison of matrix hardness at various PWHT temperatures.

Figure 11 shows the results of nanoindentation analysis to compare the hardness of intergranular ferrite and the matrix at $750{ }^{\circ} \mathrm{C}$. The analysis shows that the hardness of the matrix at $700{ }^{\circ} \mathrm{C}$ is 3.88 4.02 GPa; this is similar to that of intergranular ferrite, which is $3.94 \sim 3.98 \mathrm{GPa}$. It is considered that the transgranular strength at $750{ }^{\circ} \mathrm{C}$ is similar to the intergranular strength. Therefore, at $750{ }^{\circ} \mathrm{C}$, the grain boundary is softened by intergranular ferrite, but the matrix is softened similarly at the grain boundary, so that intergranular fracture did not occur and CGHAZ was not sensitive to PWHT cracking. 


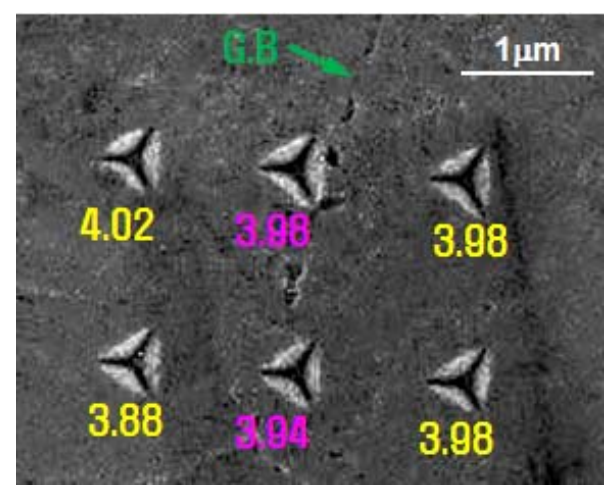

Figure 11. Nanoindentation results showing hardness at $750{ }^{\circ} \mathrm{C}$.

\subsection{Formation Mechanism of Ferrite at Prior Austenite Grain Boundary}

Figure 12 shows the results of the EPMA surface analysis for analyzing the alloy composition of the grain boundary and black band of the CGHAZ. The black band of CGHAZ is a region where $\mathrm{C}, \mathrm{W}$, and $\mathrm{Cr}$ components are concentrated. Lee's study showed that the $\mathrm{M}_{23} \mathrm{C}_{6}$ of the matrix in the CGHAZ thermal cycle dissolves, but is not fully diffused, revealing $\mathrm{C}, \mathrm{W}$, and $\mathrm{Cr}$ segregations. The line at the grain boundaries of the CGHAZ observed in the SEM microstructure of Figure 5 is the region where C is concentrated.
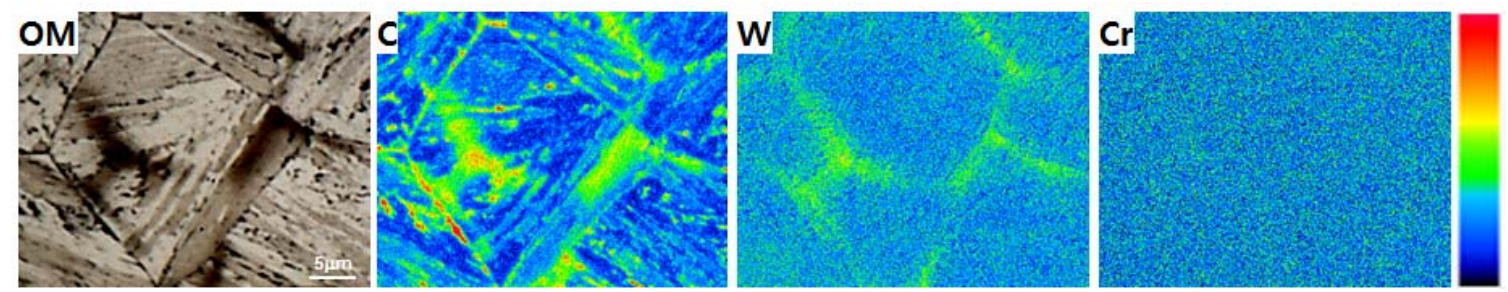

Figure 12. Electron probe micro-analyzer (EPMA) mapping results showing the distribution of elements in coarse grain heat-affected zone (CGHAZ).

In order to identify the phase of the line at the grain boundary of CGHAZ, a thin film was prepared and observed using TEM. In the Bright-field (BF) image of Figure 13a, the line at the grain boundary is seen. A diffraction pattern analysis of the $X_{1}$ and $X_{2}$ regions was performed to identify the phases of the line at the grain boundary and the matrix. As a result of the analysis, the diffraction patterns shows a Nishiyama-Wasserman orientation relationship between the martensite and the austenitic phase $\left(5.26^{\circ}\right)$ at boundaries. The line at the grain boundary was found to be austenite of Face Centered Cubic (FCC) structure and the matrix was of BCC structure, which was determined to be martensite considering the rapid cooling rate and hardness $(340 \mathrm{Hv})$ of CGHAZ. To conclude, the result of the EPMA and TEM analysis indicated that the line at the grain boundary of CGHAZ was austenite with carbon concentration.
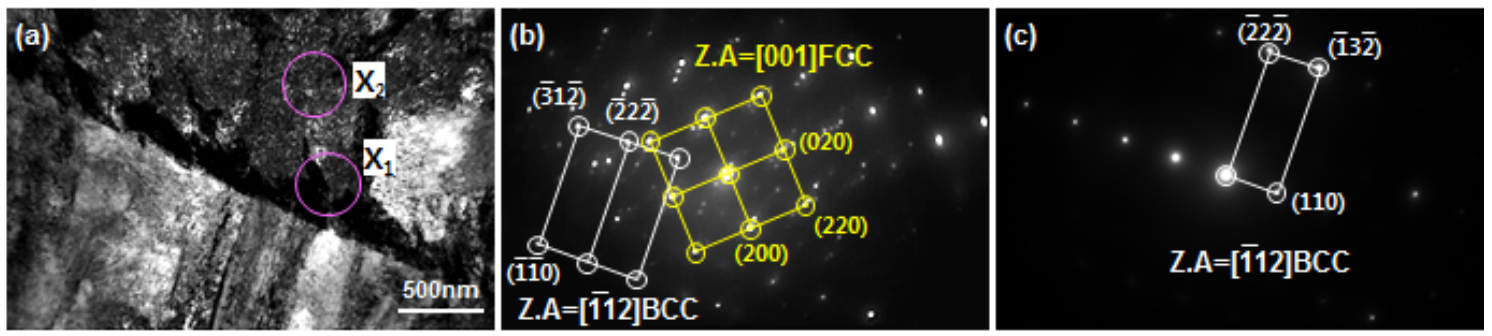

Figure 13. (a) TEM micrograph of CGHAZ; $(\mathbf{b}, \mathbf{c})$ Diffraction patterns at the regions denoted by $X_{1}$ and $X_{2}$. 
In order to investigate the reason for the generation of intergranular ferrite during PWHT, the TTT-curve, according to the alloy composition of the matrix, was obtained, as shown in Figure 14, by using JmatPro simulation. In the case of the PWHT of the alloy composition of the matrix for $30 \mathrm{~min}$ at $650{ }^{\circ} \mathrm{C}, 700{ }^{\circ} \mathrm{C}$, and $750{ }^{\circ} \mathrm{C}$, the austenite at the grain boundary of CGHAZ does not transform into ferrite, because the ferrite nose time is longer than $30 \mathrm{~min}$. However, the grain boundaries are regions where the $C, W$, and $C r$ components are depleted by the $\mathrm{M}_{23} \mathrm{C}_{6}$ precipitation, due to which the ferrite nose time decreases [31]. In such a situation, austenite at the grain boundary of CGHAZ transforms into intergranular ferrite.

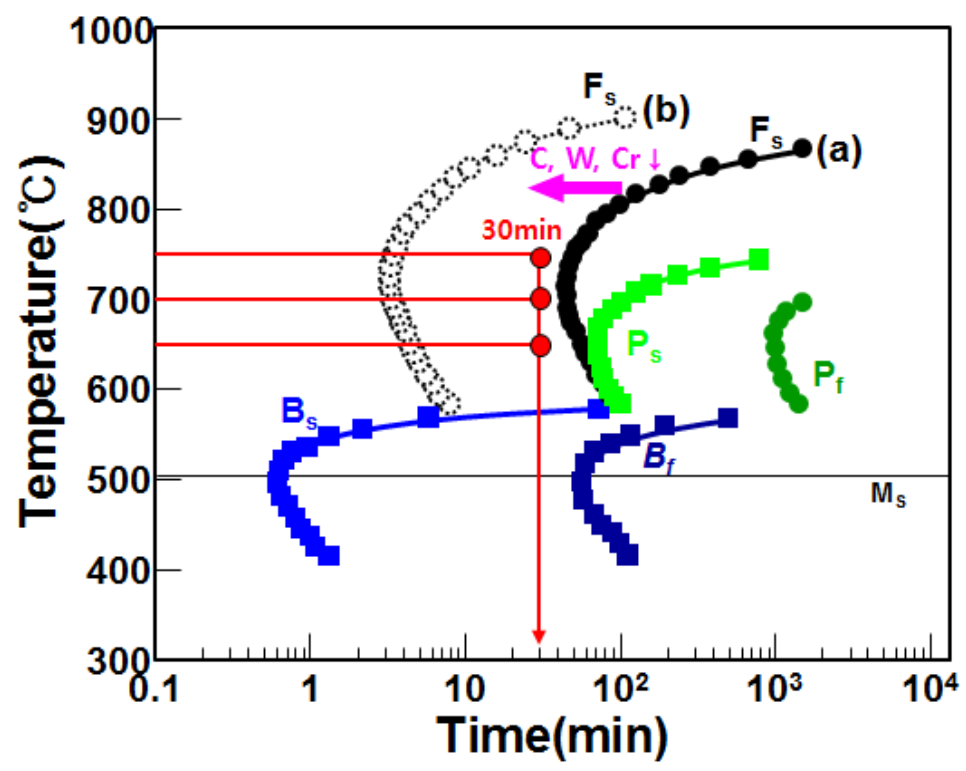

Figure 14. Time-temperature-transformation (TTT) diagrams for an alloy composition of matrix (Fe-0.07\%C-2.09Cr-1.66W) calculated with JMatPro software. (a) Ferrite nose time of matrix alloy composition; (b) Predicted ferrite nose time when C, W, Cr is depleted.

Figure 15 is a schematic diagram for explaining microstructural evolution. (a) There are precipitates at the crystal grain boundaries of the base material. (b) When heated to $1350{ }^{\circ} \mathrm{C}$, the matrix of the base material is transformed into austenite. The precipitates dissolve, and the grain size becomes coarse. The precipitates are not completely dissolved in the rapid heating of CGHAZ, and there are $\mathrm{Cr}, \mathrm{W}$, and $\mathrm{C}$ segregations. (c) When rapidly cooled to room temperature, the matrix transforms into martensite, and austenite with carbon concentration appears at grain boundaries. (d) When performing PWHT at $650{ }^{\circ} \mathrm{C}, 700{ }^{\circ} \mathrm{C}$, and $750{ }^{\circ} \mathrm{C}$, the martensite is tempered. $\mathrm{C}, \mathrm{W}$, and $\mathrm{Cr}$ are depleted at the grain boundary by $\mathrm{M} 23 \mathrm{C} 6$ precipitation, and austenite at grain boundary is transformed into ferrite.

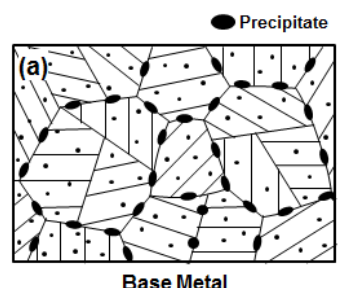

Base Metal

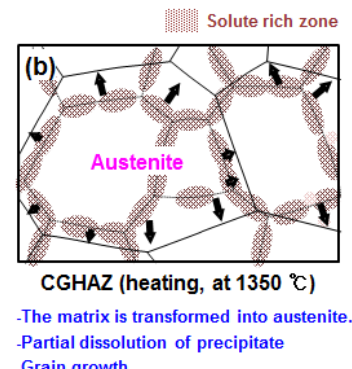

-Grain growth

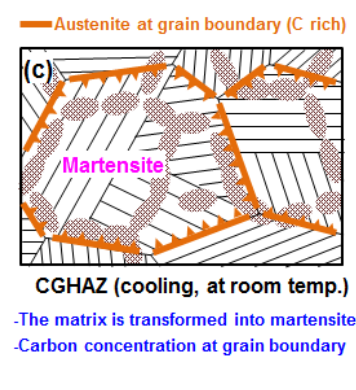

Figure 15. Schematic illustration of microstructural evolution. (a) Base metal; (b) CGHAZ (heating, at $1350{ }^{\circ} \mathrm{C}$ ); (c) CGHAZ (cooling, at room temp.); (d) PWHT (at $650,700750{ }^{\circ} \mathrm{C}$ ). 


\section{Conclusions}

PWHT cracking susceptibility and microstructural characteristics of CGHAZ in SA213-T23 were investigated at various PWHT temperatures. The findings are summarized as follows:

(1) As a result of the PWHT cracking susceptibility test of CGHAZ at $650{ }^{\circ} \mathrm{C}, 700{ }^{\circ} \mathrm{C}$, and $750{ }^{\circ} \mathrm{C}$, it was found that CGHAZ was sensitive to PWHT at $650{ }^{\circ} \mathrm{C}$ and $700{ }^{\circ} \mathrm{C}$, but not at $750{ }^{\circ} \mathrm{C}$. The surfaces at $650{ }^{\circ} \mathrm{C}$ and $700{ }^{\circ} \mathrm{C}$ contain intergranular fractures, but at $750{ }^{\circ} \mathrm{C}$, they contain transgranular fractures.

(2) In order to investigate the microstructural characteristics of CGHAZ at PWHT temperatures, microstructures were observed by etching with nital and alkaline sodium picrate etchants. Alkaline sodium picrate-etched microstructures at $650{ }^{\circ} \mathrm{C}, 700{ }^{\circ} \mathrm{C}$, and $750{ }^{\circ} \mathrm{C}$ showed white bands at grain boundaries that did not appear in nital etching. In the EPMA and TEM analyses, the white band at the grain boundaries of $650{ }^{\circ} \mathrm{C}, 700{ }^{\circ} \mathrm{C}$, and $750{ }^{\circ} \mathrm{C}$ was intergranular ferrite depleted in C, W, and Cr.

(3) The reason why an intergranular fracture appears largely at $650{ }^{\circ} \mathrm{C}$ and $700{ }^{\circ} \mathrm{C}$ and is sensitive to PWHT cracking is that the intergranular strength is lower than the transgranular strength due to ductile intergranular ferrite. The intergranular ferrite appears due to $\mathrm{C}$ and $\mathrm{Cr}$ depletion by M23C6 precipitation during PWHT. At $750{ }^{\circ} \mathrm{C}$, the surface fracture is mostly transgranular fracture, and is not susceptible to PWHT cracking. The reason is that the intergranular ferrite lowers the intergranular strength, but the transgranular strength is also lowered by the high tempering effect, so that the intergranular strength and the transgranular strength are similar to each other.

(4) A line observed at the grain boundary of CGHAZ was found to be austenite with carbon concentration, on the basis of EPMA and TEM analysis.

(5) In the case of the PWHT of the alloy composition of the matrix for $30 \mathrm{~min}$ at $650{ }^{\circ} \mathrm{C}, 700{ }^{\circ} \mathrm{C}$, and $750{ }^{\circ} \mathrm{C}$, the austenite at the grain boundary of CGHAZ does not transform into ferrite, because the ferrite nose time in the TTT curve is longer than $30 \mathrm{~min}$. However, the grain boundary is a region where $\mathrm{C}, \mathrm{W}$, and $\mathrm{Cr}$ are depleted by $\mathrm{M}_{23} \mathrm{C}_{6}$ precipitation with high $\mathrm{C}, \mathrm{W}$, and $\mathrm{Cr}$ components. When $\mathrm{C}, \mathrm{W}$, and $\mathrm{Cr}$ are depleted, the ferrite nose time becomes shorter than $30 \mathrm{~min}$, so that austenite at the grain boundary of CGHAZ is then transformed into ferrite.

Author Contributions: S.-H.L., H.-S.N., K.-W.L. and C.-Y.K. conceived and designed the experiments; S.-H.L. and J.-Y.L. performed the experiments; S.-H.L., H.-S.N. and C.-Y.K. analyzed the data; S.-H.L. wrote this paper.

Funding: This research received no external funding.

Acknowledgments: This work was supported by a National Research Foundation of Korea (NRF) grant funded by the Korea government (MSIP) (No. 2012R1A5A1048294).

Conflicts of Interest: The authors declare no conflict of interest. The funding sponsors had no role in the design of the study; in the collection, analyses, or interpretation of data; in the writing of the manuscript, and in the decision to publish the results.

\section{References}

1. Klueh, R.; Nelson, A. Ferritic/martensitic steels for next-generation reactors. J. Nucl. Mater. 2007, 371, 37-52. [CrossRef]

2. Bendick, W.; Gabrel, J.; Hahn, B.; Vandenberghe, B. New low alloy heat resistant ferritic steels T/P23 and T/P24 for power plant application. Int. J. Press. Vessels Pip. 2007, 84, 13-20. [CrossRef]

3. Haarmann, K.; Kottmann, G.; Vaillant, J. The T23/24 Book; Vallourec \& Mannesmann: Dusseldorf-Rath, Germany, 2000.

4. Nawrocki, J.; Dupont, J.; Robino, C.V.; Marder, A. The Stress-Relief Cracking Susceptibility of a New Ferritic Steel-Part I: Single-Pass Heat-Affected Zone Simulations; Sandia National Labs.: Livermore, CA, USA, 1999.

5. Nawrocki, J.; Dupont, J.; Robino, C.; Puskar, J.; Marder, A. The mechanism of stress-relief cracking in a ferritic alloy steel. Weld. J. N. Y. 2003, 82, 25-S. 
6. Masuyama, F.; Yokoyama, T.; Sawaragi, Y.; Iseda, A. Service Exposure and Reliability Improvement: Nuclear, Fossil, and Petrochemical Plants; ASME: New York, NY, USA, 1994; Volume 288, pp. 141-146.

7. Jiménez, J.A.; Carsí, M.; Ruano, O.A. Effect of rhenium on the microstructure and mechanical behavior of Fe-2.25 Cr-1.6 W-0.25 V-0.1 C bainitic steels. J. Mater. Sci. Technol. 2017, 33, 1487-1493. [CrossRef]

8. Di Gianfrancesco, A. Materials for Ultra-Supercritical and Advanced Ultra-Supercritical Power Plants; Woodhead Publishing: Cambridge, UK, 2016.

9. Wang, B.; Xueyuan, X.; Feng, Z.; Anfang, Q.; Zhengran, L.; Bo, Z.; Yongqiang, J.; Xiaoli, L. Research on water wall tubes and welded joints of 1000 MW USC tower boiler. In Proceedings of the 7th International Conference on Advances in Materials Technology for Fossil Power Plants, Waikoloa, HI, USA, 22-25 October 2013.

10. Viswanathan, R. Advances in materials technology for fossil power plants. In Proceedings of the Fifth International Conference, Marco Island, FL, USA, 3-5 October 2007; ASM International: Materials Park, OH, USA, 2008.

11. Heo, N.; Chang, J.; Kim, S.-J. Elevated temperature intergranular cracking in heat-resistant steels. Mater. Sci. Eng. A 2013, 559, 665-677. [CrossRef]

12. Park, K.; Kim, S.; Chang, J.; Lee, C. Post-weld heat treatment cracking susceptibility of T23 weld metals for fossil fuel applications. Mater. Des. 2012, 34, 699-706. [CrossRef]

13. Chang, J.; Kim, B.; Heo, N. Stress relief cracking on the weld of T/P23 steel. Procedia Eng. 2011, 10, 734-739. [CrossRef]

14. Heo, N.; Chang, J.; Yoo, K.; Lee, J.; Kim, J. The mechanism of elevated temperature intergranular cracking in heat-resistant alloys. Mater. Sci. Eng. A 2011, 528, 2678-2685. [CrossRef]

15. Chang, J.; Heo, N.; Lee, C. Intergranular cracking susceptibility of $2.25 \mathrm{Cr} 1.3 \mathrm{~W}$ and $9 \mathrm{Cr} 1 \mathrm{MoVNb}$ weld metals at elevated temperatures. Met. Mater. Int. 2010, 16, 981-985. [CrossRef]

16. Chang, J.; Heo, N.; Lee, C. Effects of mo addition on intergranular cracking behavior of 2.25CrW (P23) weld metal at elevated temperatures. Met. Mater. Int. 2011, 17, 131-135. [CrossRef]

17. Belde, M.; Springer, H.; Inden, G.; Raabe, D. Multiphase microstructures via confined precipitation and dissolution of vessel phases: Example of austenite in martensitic steel. Acta Mater. 2015, 86, 1-14. [CrossRef]

18. Raabe, D.; Sandlöbes, S.; Millán, J.; Ponge, D.; Assadi, H.; Herbig, M.; Choi, P.P. Segregation engineering enables nanoscale martensite to austenite phase transformation at grain boundaries: A pathway to ductile martensite. Acta Mater. 2013, 61, 6132-6152. [CrossRef]

19. Lee, K.; Lee, S.; Na, H.; Kang, C. Ghost microstructure evolution and identification in the coarse grain heat affected zone of 2.25 Cr-1Mo-V-Ti steel using tint etching. Mater. Charact. 2016, 121, 31-39. [CrossRef]

20. Lee, S.H.; Na, H.S.; Lee, K.W.; Choe, Y.; Kang, C.Y. Microstructural characteristics and M23C6 precipitate behavior of the course-grained heat-affected zone of T23 steel without post-weld heat treatment. Metals 2018, 8, 170. [CrossRef]

21. Dhooge, A.; Vekeman, J. New generation $21 / 4$ Cr steels T/P 23 and T/P 24 weldability and high temperature properties. Weld. World 2005, 49, 75-93. [CrossRef]

22. Shinya, T.; Tomita, Y. Effect of calcium treatments and strain rate on reheat cracking of vanadium-modified 2.25 cr-1mo steel. Mater. Charact. 1998, 40, 221-225. [CrossRef]

23. Nevasmaa, P.; Salonen, J. Reheat cracking susceptibility and toughness of $2 \%$ CrMoWVNb P23 steel welds. Weld. World 2008, 52, 68-78. [CrossRef]

24. Kaneko, K.; Fukunaga, T.; Yamada, K.; Nakada, N.; Kikuchi, M.; Saghi, Z.; Barnard, J.S.; Midgley, P.A. Formation of M23C6-type precipitates and chromium-depleted zones in austenite stainless steel. Scr. Mater. 2011, 65, 509-512. [CrossRef]

25. Thorvaldsson, T.; Dunlop, G. Grain boundary Cr-depleted zones in Ti and $\mathrm{Nb}$ stabilized austenitic stainless steels. J. Mater. Sci. 1983, 18, 793-803. [CrossRef]

26. Almubarak, A.; Abuhaimed, W.; Almazrouee, A. Corrosion behavior of the stressed sensitized austenitic stainless steels of high nitrogen content in seawater. Int. J. Electrochem. 2013, 2013. [CrossRef]

27. Nakamichi, H.; Sato, K.; Miyata, Y.; Kimura, M.; Masamura, K. Quantitative analysis of Cr-depleted zone morphology in low carbon martensitic stainless steel using Fe-(s) TEM. Corros. Sci. 2008, 50, 309-315. [CrossRef]

28. Gaško, M.; Rosenberg, G. Correlation between hardness and tensile properties in ultra-high strength dual phase steels-short communication. Mater. Eng. 2011, 18, 155-159. 
29. Shen, Y.-L.; Chawla, N. On the correlation between hardness and tensile strength in particle reinforced metal matrix composites. Mater. Sci. Eng. A 2001, 297, 44-47. [CrossRef]

30. Chenna, K.S.; Kumar, G.N.; Jha Abhay, K.; Bhanu, P. On the prediction of strength from hardness for copper alloys. J. Mater. 2013, 2013. [CrossRef]

31. Na, H.S.; Kim, B.H.; Lee, S.H.; Kang, C.Y. Thermodynamic alloy design of high strength and toughness in $300 \mathrm{~mm}$ thick pressure vessel wall of $1.25 \mathrm{Cr}-0.5 \mathrm{Mo}$ steel. Metals 2018, 8, 70. [CrossRef]

(c) (1)

(c) 2018 by the authors. Licensee MDPI, Basel, Switzerland. This article is an open access article distributed under the terms and conditions of the Creative Commons Attribution (CC BY) license (http://creativecommons.org/licenses/by/4.0/). 